\title{
Biochemical and Morphological Responses to Abiotc Elicitor Chitin in Suspension-Cultured Sugarcane Cells
}

\author{
Maria Izabel Gallão ${ }^{1 *}$, Ângelo Luiz Cortelazzo ${ }^{2}$, Manuel Pedro Salema Fevereiro ${ }^{3}$ and Edy \\ Sousa de Brito ${ }^{4}$ \\ ${ }^{I}$ Departamento de Biologia; Universidade Federal do Ceará; Campus do Pici; Bloco 906; 60455-760; Fortaleza - \\ CE - Brasil. ${ }^{2}$ Universidade Estadual de Campinas; Campinas - SP - Brasil. ${ }^{3}$ Instituto de Tecnologia Química e \\ Biológica; Oeiras; P-2780; Portugal. ${ }^{4}$ Embrapa Agroindústria Tropical; Fortaleza - CE - Brasil
}

\begin{abstract}
Cells of Saccharum officinarum submitted to hydrolyzated chitin for 1 to 8 h produced phenolic compounds. These alterations were observed through cytochemical methods using Toluidine Blue and Phloroglucinol/HCl. After $4 \mathrm{~h}$, besides cell wall change, there was a change in nuclear pattern of chitin treated cells. There was a $96 \%$ increase in nuclear area in $6 \mathrm{~h}$ chitin treated material, as observed by Feulgen reaction. The treated cells showed chromatin compacted regions and a degeneration process of nucleoli. In the outer areas of cell wall, there was a polysaccharide desagregation, confirming results obtained for different plants with the use of other elicitors. Peroxidase activity was maximal after $4 \mathrm{~h}$ and decreased progressively. PAL activity started to increase at $4 \mathrm{~h}$ of incubation. These results showed that chitin hydrolyzate stimulated a defense response in sugarcane cells.
\end{abstract}

Key words: Chitin, elicitation, peroxidase, PAL, sugarcane, tissue culture

\section{INTRODUCTION}

Plant cells can respond to pathogenic attacks by activating a series of defense reactions (Ride 1992; Boller, 1995; Hawkins and Boudet, 1996). The defense system of plants includes biochemical mechanisms such as accumulation of phenolic compounds linked to cell wall, synthesis of phytoalexin, activation of enzymes involved in lignification, synthesis of hydrolytic enzymes such as chitinases and $\beta-1,3$-glucanases, and formation of cell wall structural proteins, including hydroxyproline-rich glycoproteins (Dixon et al., 2002; Verpoorte et al., 2002). Phenylpropanoids, whose metabolism may be initiated by the activation of enzymes that participate in initial defense reactions, are important for the survival of cells under stress (Dixon and Paiva, 1995).

Besides lignification, other cellular alterations have been observed after the addition of biologically active substances to cell suspension cultures. Among these substances, some oligosacharides obtained from xiloglucans (McDougall and Fry, 1990; Joseleau et al., 1996), pectins (Aldington et al., 1991), chitin and chitosan (Peltonen et al., 1997) have been studied. Chitin, a cell wall polysaccharide from fungi, is an active elicitor of lignification in wounded wheat leaves and wheat suspension-cultured cells (Gotthardt and Grambow, 1992; Stacey and Shibuya, 1997; Shibuya and Minami, 2001; Ramonell al., 2002).

\footnotetext{
*Author for correspondence: edybel@ufc.br
} 
Peroxidases (EC.1.11.1.7) and phenylalanine ammonia-lyase (PAL) (EC. 4.3.1.5.) are one of the enzymes activated in response to a stress caused by fungi. Peroxidases are widely distributed in the plant kingdom and are associated with several physiological processes, including growth regulation and cellular lengthening (Goldberg et al., 1986), auxin metabolism (Grambow and Langenbeck-Schwich, 1983) and lignification (Melo et al., 1995; McGhie et al., 1997). PAL catalyzes the first reaction of the phenylpropanoid biosynthetic pathway involving the conversion of L-phenylalanine into trans-cinamic acid through a non-oxidative deamination reaction (Rohde et al., 2004).

Lignin is a complex heterogeneous phenolic polymer whose deposition can be induced in many cell types by diseases or wounds, indicating that the genes involved in the biosynthesis respond to developmental and environmental stimuli (Dixon et al., 2002). This process can be analysed using plant cell cultures where the cells are stimulated by the substances known to induce lignin deposition (Grima-Pettenati and Goffner, 1999).

In this work, the morphological alterations and the changes in peroxidase and PAL activities in Saccharum officinarum cells cultivated in suspension and exposed to a chitin hydrolyzed solution were investigated.

\section{MATERIAL AND METHODS}

Saccharum officinarum cells derived from calluses were sub-cultured every 2-3 weeks into Murashige and Skoog (1962) medium containing $3 \mathrm{mg} \mathrm{L}^{-1}$ of 2,4-dichlorophenoxiacetic acid $\left(\mathrm{MS}_{3}\right)$. Cell suspensions were initiated by transferring the portions of callus to $20 \mathrm{~mL}$ of liquid medium. Cultures were maintained at $25 \pm 1^{\circ} \mathrm{C}$ in the dark and constant agitation $(120 \mathrm{~g})$. The hydrolyzed chitin from the shells was acquired from Fine Chemical Kito (Palhoça, Santa Catarina State, Brazil), prepared as described by Villegas and Brodelius (1990) and $80 \mu \mathrm{L}$ was added to the culture medium immediately following the inoculation of 2-d-old cell suspensions cultures to give a $200 \mu \mathrm{g} \mathrm{mL}^{-1}$ final concentration. Flasks $(125 \mathrm{~mL})$ with $80 \mathrm{~mL}$ culture medium were used. Cells were collected after 1, 2, 3, 4, 6 and $8 \mathrm{~h}$ of elicitor addition. The control cultures received sterile distilled water and samples $(\mathrm{N}=3)$ were also collected at each time. Each experiment was repeated three times. Suspensions were filtered on sinterized glass funnels (40-90 $\mu \mathrm{m}$ porosity) and fixed with $2 \%$ paraformaldehyde and $0.1 \%$ glutaraldehyde solution in $50 \mathrm{mM}$ phosphate buffer, $\mathrm{pH} 7.0$ for $4 \mathrm{~h}$ at $4^{\circ} \mathrm{C}$. Dehydration was made in ethanol solutions and clearing in xilol for $30 \mathrm{~min}$, followed by immersion in paraffin and serial cuts with $7 \mu \mathrm{m}$ thickness. After removal of paraffin, the material was stained with: Toluidine Blue (TB) $0.025 \% \quad\left(\lambda_{\max }=620-630 \mathrm{~nm}\right)$ in McIlvaine's buffer ( $\mathrm{pH} 4.0)$ for detection of anionic groups and metachromasy $\left(\lambda_{\max }<580-590\right.$ nm) (Vidal, 1977); Periodic Acid-Schiff (PAS) reaction for the detection of neutral polysaccharides, according to Cortelazzo (1992). The reaction with phloroglucinol/HCl (Vallet et al., 1996) was employed for lignin detection. Feulgen's reaction (Mello and Vidal, 1978) for DNA detection was employed and nuclei diameter measurement was performed on ten cells per slide $(\mathrm{N}=40)$ from the treated and control materials. For Transmission Electron Microscopy (TEM), cells were fixed for $18 \mathrm{~h}$ in a solution containing $2.5 \%$ glutaraldehyde, $3 \%$ sucrose and $5 \mathrm{mM} \mathrm{CaCl}_{2}$ in phosphate buffer ( $\mathrm{pH}$ 7.2), followed by several washes and post-fixation with $1 \%$ osmium tetroxide. Dehydration was made in ketone, followed by sample inclusion in resin Spurr (1969). Ultra-thin cuts were stained with uranyl acetate and lead citrate. Observations were made using a TEM Zeiss (Leo 906) at $80 \mathrm{kv}$. Peroxidase activity of culture medium was assayed spectrophotometrically through the oxidation of guaiacol (George, 1953). Phenylalanine ammonialyase (PAL) activity was assayed in lyophilized material (Dörnenburg and Knorr, 1997). Enzyme activity was analyzed by ANOVA-one way and means were compared by Tukey's test or $t$ test to compare two averages of treatments $(P \leq 0.05)$.

\section{RESULTS}

The results obtained by staining methods are presented in Table 1. PAS reaction, which identified neutral sugars in the cell wall, revealed control cells with a more regular form (Fig. 1A), while in $6 \mathrm{~h}$ heterogeneity, many elongated cells were observed (Fig. 1B). Control cells presented metacromasy when stained with Toluidine Blue. 
Table 1- Structures stained in sugarcane cells eliceted by a chitin hydrolizate.

\begin{tabular}{|c|c|c|c|c|c|c|c|}
\hline \multirow{2}{*}{ Structure $^{a}$} & \multirow{2}{*}{ Control } & \multicolumn{6}{|c|}{ Chitin eliceted } \\
\hline & & 1h & $2 \mathrm{~h}$ & $3 \mathbf{h}$ & $4 h$ & 6h & $8 h$ \\
\hline \multicolumn{8}{|l|}{ Cell wall } \\
\hline Acidic sugars (TB) & $+++{ }^{\mathrm{b}}$ & +++ & ++ & + & ++ & +++ & +++ \\
\hline Neutral sugars (PAS) & +++ & +++ & +++ & +++ & +++ & +++ & +++ \\
\hline Metacromasy (TB) & +++ & ++ & + & - & + & ++ & +++ \\
\hline Lignin (Phloroglucinol) & - & + & ++ & +++ & ++ & + & - \\
\hline \multicolumn{8}{|l|}{ Cytoplasm } \\
\hline Protein (XP) & ++ & + & + & + & + & ++ & ++ \\
\hline Starch grain (PAS) & +++ & +++ & +++ & +++ & +++ & +++ & +++ \\
\hline
\end{tabular}

${ }^{\mathrm{a}} T B$ Toluidine Blue, $P A S$ Periodic Acid Schiff, XP Xylidine Ponceau

${ }^{\mathrm{b}}(-)$ no stain, (+) fairly stained, (++) stained, (+++) strongly stained

This staining was reduced in chitin treated cells. The staining intensity reduction was continuous until $3 \mathrm{~h}$ and after $4 \mathrm{~h}$, the staining intensity again increased (Table 1).

A positive reaction for phloroglucinol/HCL was not observed in control material (Fig. 1C), but treated material presented a progressive positive staining up to $3 \mathrm{~h}$ of incubation (Table 1), followed by a decrease at $8 \mathrm{~h}$ (Fig. 1D).

Feulgen reaction in control cells revealed the presence of smaller nuclei $(9.18 \pm 1.5 \mu \mathrm{m}$, Fig. $1 \mathrm{E})$, in relation to treated cells, which presented diameters of $11.2 \pm 2.5$ and $11.3 \pm 2.2 \mu \mathrm{m}$ after 4 and $6 \mathrm{~h}$, respectively (Fig. 1F). After $8 \mathrm{~h}$ of incubation, the nuclei diameters showed similar value $(8.69 \pm 1.9 \mu \mathrm{m})$ as that of control material. Electron micrograph of control material showed less compacted chromatin in nuclei (Fig. 2A), while in material submitted to chitin hydrolyzate, cells with greater chromatin compactation and degenerating nucleoli were observed (Figs. 2B-C).
It was possible to observe the integrity of cell walls in control material, with their characteristic fibrilar aspect (Fig. 2D), while a cell wall polysaccharide disaggregation was observed in treated material. This phenomenon consisted in partial release of a narrow fringe of microfibrils, which became oriented perpendicular to the surface and progressively individualized (Fig. 2E) and an enhanced reactivity to uranyl acetate staining was clearly visible.

After $3 \mathrm{~h}$, peroxidase isozymes activity in culture medium increased for the control cells. This increase was continuous until $8 \mathrm{~h}$. For chitin treated cells, peroxidase isozymes activity started to increase at $2 \mathrm{~h}$ and reached a peak at $4 \mathrm{~h}$, followed by a decreased at 6 and $8 \mathrm{~h}$ (Table 2). PAL activity was only detected at $4 \mathrm{~h}$ after incubation (Table 2). There was a difference between the control, with treated cells and higher values for chitin treated cells. 

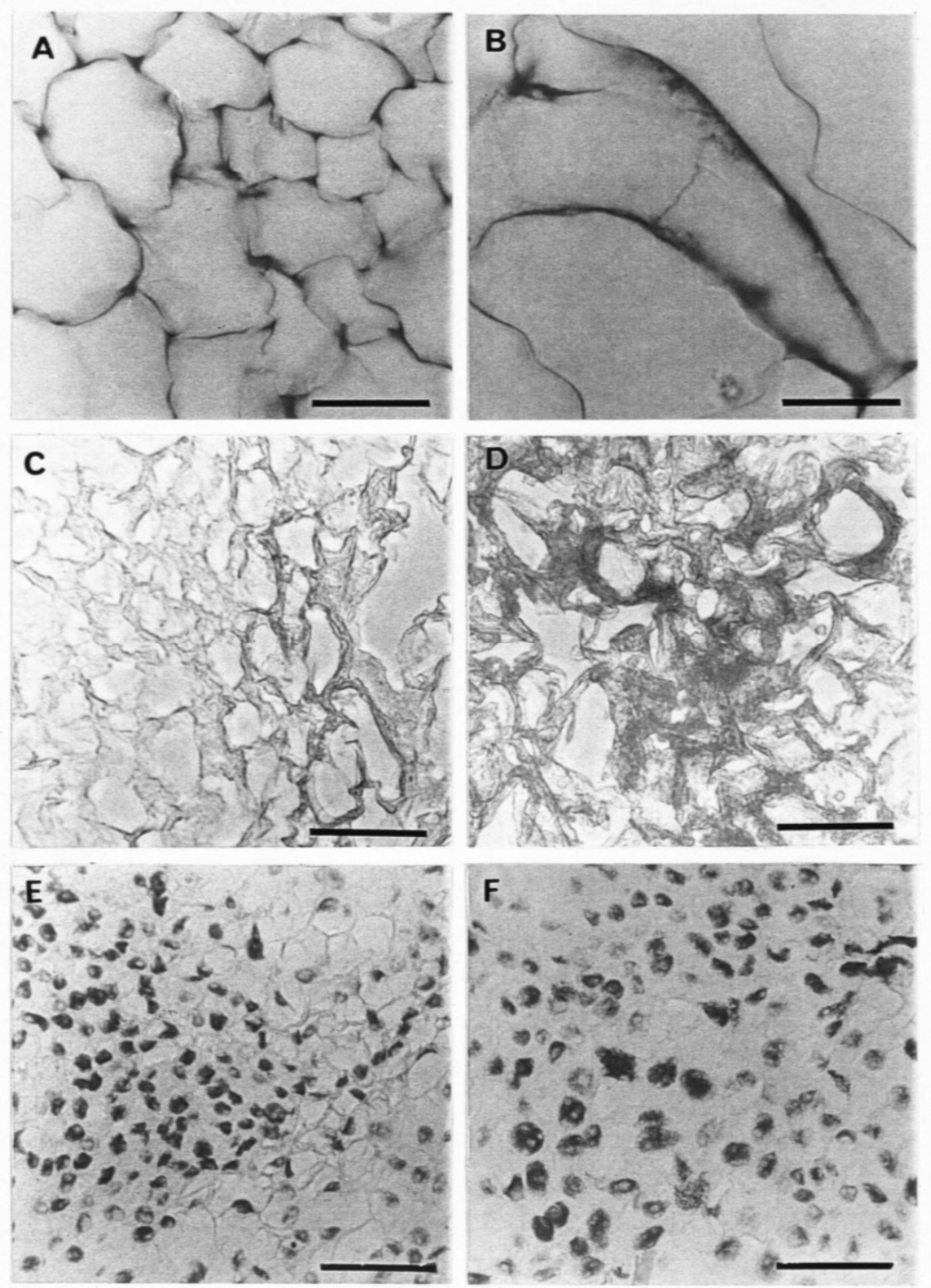

Figure 1 - Suspension cultured cells of Saccharum officinarum. A, C and E: Control cells; B, D and F: $6 \mathrm{~h}$ after treatment with oligosaccharides. A-B: PAS reaction. Note the stained polysaccharides of cell walls and the elongated cells of treated material. C-D: Phloroglucinol/ $\mathrm{HCl}$ reaction, with a positive response after $6 \mathrm{~h}$ of incubation. E-F: Feulgen reaction. Note the nuclei smaller in control cells. Bars: A e B: $11 \mu \mathrm{m} ; \mathrm{C}, \mathrm{D}, \mathrm{E}$, e F: $36 \mu \mathrm{m}$. 

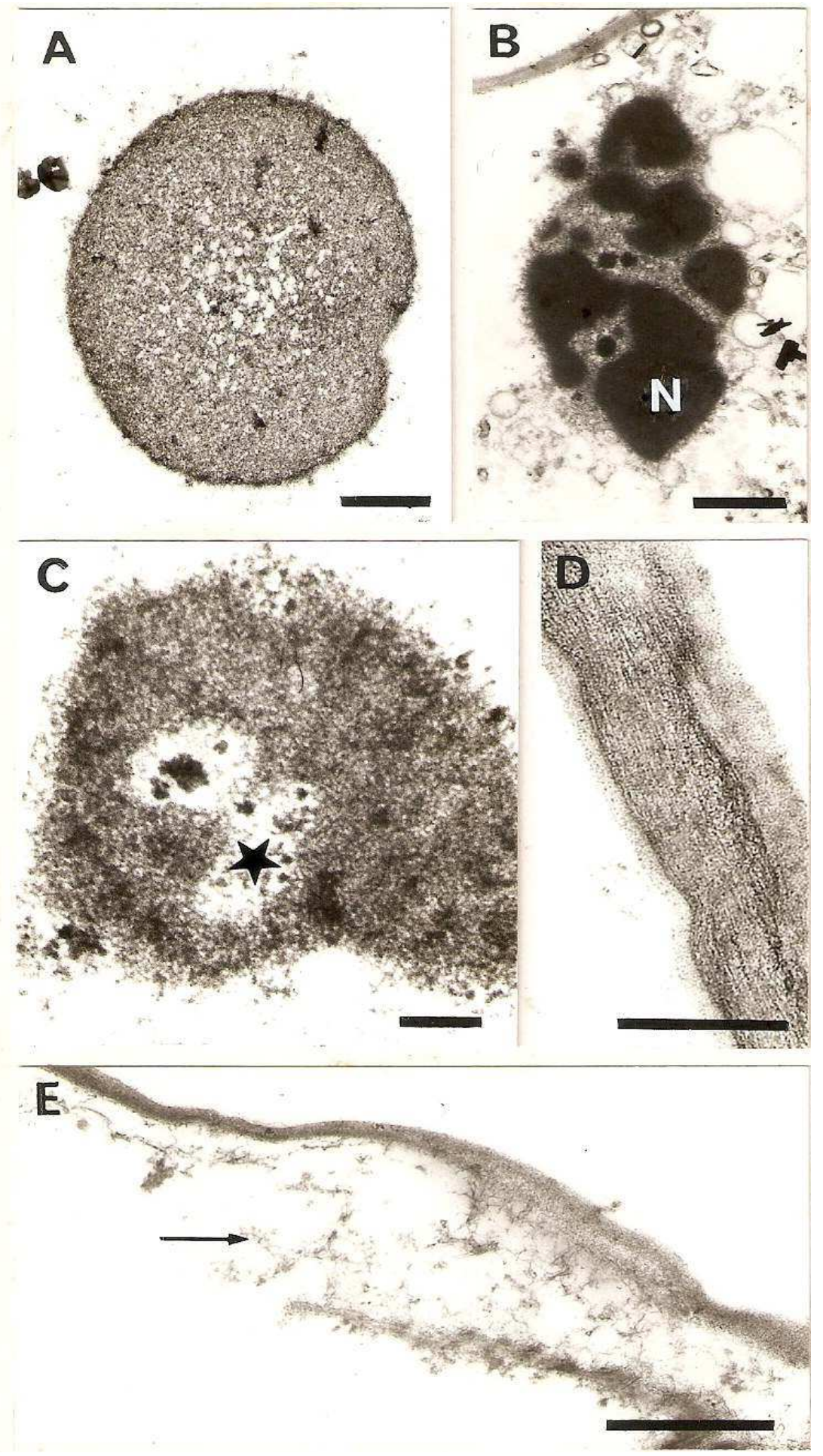

Figure 2 - Electron micrographies of control (A and D) and treated (B, C and E) material. A - Aspect of nuclei $(\mathrm{N})$ with less compacted chromatin; B-C - Aspect of nuclei $(\mathrm{N})$ with greater chromatin compactation and degenerating nucleoli $(\star)$ were observed. D - Cell wall of control material, with their fibrilar aspect. E: Cell wall of treated material, showing polysaccharide disaggregation with a characteristic narrow fringe of microfibrils (arrows). Bars: A e B: $1 \mu \mathrm{m}$; C: 0,2 $\mu \mathrm{m}, \mathrm{D}: 0,6 \mu \mathrm{m}$; E: $1 \mu \mathrm{m}$. 
Table 2 - Activities of peroxidases and phenylalanine ammonia-lyase of control and chitin-treated sugar cane cells.

\begin{tabular}{ccccc}
\hline \multirow{2}{*}{ Time (h) } & \multicolumn{3}{c}{ Enzyme } \\
\cline { 2 - 5 } & \multicolumn{2}{c}{ POD $\left(\mathbf{U ~ L}^{-\mathbf{1}}\right.$ of medium) } & \multicolumn{2}{c}{ PAL $\left(\mathbf{U ~ K g}^{-1}\right.$ of cells) } \\
\hline & Control & Chitin & Control & Chitin \\
2 & $379^{\mathrm{d}, \mathrm{e}} \pm 33$ & $193^{\mathrm{d} *} \pm 80$ & ND & ND \\
3 & $302^{\mathrm{e}} \pm 22$ & $264^{\mathrm{c}, \mathrm{d}} \pm 48$ & $\mathrm{ND}$ & $\mathrm{ND}$ \\
4 & $517^{\mathrm{d}} \pm 15$ & $377^{\mathrm{c} *} \pm 55$ & $\mathrm{ND}$ & $\mathrm{ND}$ \\
6 & $797^{\mathrm{c}} \pm 32$ & $1220^{\mathrm{a} *} \pm 61$ & $48^{\mathrm{c}} \pm 4$ & $108^{\mathrm{c} *} \pm 8$ \\
8 & $1009^{\mathrm{b}} \pm 69$ & $1018^{\mathrm{b}} \pm 68$ & $117^{\mathrm{b}} \pm 8$ & $148^{\mathrm{b} * \pm 12}$ \\
\hline & $1257^{\mathrm{a}} \pm 114$ & $969^{\mathrm{b} *} \pm 112$ & $160^{\mathrm{a}} \pm 8$ & $187^{\mathrm{a} *} \pm 3$ \\
\hline
\end{tabular}

Values are the mean $\pm \mathrm{SD} ; n=3$. ND $=$ Not detected. Within a line, means with different letters are significantly different (Tukey's test, $P<0.05)$. Within each time, means for chitin-treated cells marked with an asterisk differ from the controls $(t$ test, $P<0.05)$.

\section{DISCUSSION}

In the present work, the material treated with chitin hydrolyzate was less stained with TB than the control, indicating that sugarcane cells isoenzyme as a consequence of various types of stress or variations in physiological conditions are well documented, and sequential relationships between the cationic and anionic isoenzymes have been demonstrated (Gaspar et al., 1991).

The phenylpropanoid precursors biosynthesis is controlled partly by PAL. This enzyme activity increased dramatically in sugarcane cell cultures treated with chitin oligomers. An increase in PAL activity was related to lignification in elicited pine cell cultures (Campbell and Ellis, 1992), potato cell cultures (Dörnenburg and Knorr, 1997), wheat (Vander et al., 1998) and Citrus aurantium (Gallão et al., 2007). The increase in PAL activity detected here reinforced these observations, since this enzyme was important in lignin biosynthesis.

Thus, it could be concluded that sugarcane cells cultivated in suspension responded to chitin hydrolyzate producing lignin in the first $6 \mathrm{~h}$ of elicitation, but the culture had the capacity to restore their initial values and normal conditions of cultivation after $8 \mathrm{~h}$ of treatment. Elicitators such as chitin have a potential to be used in tests to evaluate the defence mechanisms to biotic stress such as fungal attack.

\section{ACKNOWLEDGMENTS}

We wish to thank Capes/PICDT-Brazil for supporting M.I. Gallão

\section{RESUMO}

Células de Saccharum officinarum quando submetidas a quitina hidrolisada por 1 a $8 \mathrm{~h}$ produziram material fenólico. Essas alterações foram observadas por meio de métodos citoquímicos como o Azul de Toluidina e Floroglucinol/ $\mathrm{HCl}$. Após 4 h, além das mudanças nas paredes celulares houve uma mudança no padrão nuclear das células tratadas com quitina. Por observação da reação de Feulgen, houve um aumento de $96 \%$ na área nuclear no material em 6h. Para as células tratadas foram observadas regiões de cromatina compactada e um processo de degeneração do nucléolo. Nas áreas externas da parede celular existia uma desagregação dos polisacarídios confirmando os resultados obtidos para diferentes plantas com o uso de outros elicitores. A atividade da peroxidase foi maxima após $4 \mathrm{~h}$ e então decresceu progressivamente. A atividade da PAL aumentou a partir de $4 \mathrm{~h}$ de incubação. Estes resultados mostram que o hidrolisado de quitina estimula as respostas de defesa em células de cana.

\section{REFERENCES}

Aldington S., McDougall, G.J. and Fry, S.C. (1991), Structure-activity relationships of biologically active oligosaccharides. Plant Cell Environmental, 14, 625636.

Begnami, C.N. and Cortelazzo, A.L. (1996), Cellular alterations during accelerated aging of French bean seeds. Seed Science and Technology, 24, 295-303.

Boller, T. (1995), Chemoperception of microbial signals in plant cells. Annu Rev Plant Physiology and Plant Molecular Biology, 46, 189-214. 
Bradford, M.M. (1976), A rapid and sensitive method for the quantitation of microgram quantities of protein utilizing the principle of protein-dye binding. Anal Biochemical, 72, 248-254.

Brett, C. and Waldron, K. (1990), In: Black M, Chapman J (eds) Physiology and biochemistry of plant cell walls. Unwin Hyman London. pp 193.

Cahill, D.M. and McComb, J.A. (1992), A comparison of changes in phenylalanine ammonia-lyase activity, lignin and phenolic synthesis in the roots of Eucalyptus calophylla (field resistant) and $E$. marginata (susceptible) when infected with Phytophora cinnamomi. Physiology and molecular Plant Pathology, 40, 315-332.

Campbell, M.M and Ellis, B.E. (1992), Fungal elicitormediated responses in pine cell cultures. I. Induction of phenylpropanoid metabolism. Planta, 186, 409-417.

Clifford, M.N. (1974), Specificity of acidic phloroglucinol reagents. Journal Chromatography, 94, 321-324.

Cortelazzo, A.L.; Marais, M.F. and Joseleau, J.P. (1996), Changes in peroxidases in the suspension culture of Rubus fruticosus during growth. Plant Cell Tissue and Organ Culture, 46, 27-33.

Cortelazzo, A.L. (1992), Starch detection and dosage in Canavalia ensiformis and C. gladiata cotyledons, during the plantlet development. Revista brasileira de Botânica, 15, 157-16.

Dixon, R.A.; Achnine, L.; Kota C.; Liu, C.; Redy, M.S.S. and Wang L. (2002), The phenylpropanoid pathway and plant defense - a genomics perspective. Molecular Plant Pathology, 3, 371-390.

Dixon, R.A. and Paiva N.L. (1995), Stress-induced phenylpropanoid metabolism. Plant Cell, 7, 10851097.

Dörnenburg, H. and Knorr, D. (1997), Evaluation of elicitor- and high-pressure-induced enzymatic browning utilizing potato (Solanum tuberosum) suspension cultures as a model system for plant tissues. Journal of Agriculture and Food Chemistry, 45, 4173-4177.

Fry, S.C. (1986), Cross linking of matrix polymers in the growing cell walls of Angiosperms. Annual Review Plant Physiology, 37, 165-166.

Gallão, M.I.; Cortelazzo, A.L.; Fevereiro, M.P.S.; Brito, E.S. (2007), Response to chitin in suspensioncultured Citrus aurantium cells. Brazilian Journal of Plant Physiology, 19(1), 66-76.

Gaspar, T.H.; Penel, C.; Hagege, D. and Greppin, H. (1991), Peroxidases in plant growth, differentiation, and development processes. In: Lobarzewski, J.; Greppin, H.; Penel, C. and Gaspar, T.H. (eds) Biochemical, molecular and physiological aspects of plant peroxidases. University of Geneva, pp 249-280.

George, P. (1953), Intermediate compound formation with peroxidase and strong oxidizing agents. Journal of Biology Chemistry, 201, 413-451.
Goldberg, R.; Imberty, A. and Chu-Ba, J. (1986), Development of isoperoxidases along the growth gradient in the mung bean hypocotyl. Phytochemistry, 25, 1271-1274.

Gotthard, U. and Grambow, H.J. (1992), Near-isogenic wheat suspension cultures: establishment, elicitor induced peroxidase activity and potential use in the study of host/pathogen-interactions. Journal of Plant Physiology, 139, 659-665.

Grambow, H.J. and Langenbeck-Schwich (1983), The relationship between oxidaseactivity, peroxidase activity, hydrogen peroxidase and phenolic compounds in the degradation of indole-3-acetic acid in vitro. Planta, 157, 131-137.

Grima-Pettenati, J. and Goffner, D. (1999), Lignin genetic engineering revisited. Plant Science, 145, 51-65.

Hadwiger, L.A. and Adams, M.J. (1978), Nuclear changes associated with the host-parasite interaction between Fusarium solani and peas. Physiology Plant Pathology, 12, 63-72.

Hawkins, S. and Boudet, A. (1996), Wound-induced lignin and suberin deposition in a woody angiosperm (Eucalyptus gunni Hook): histochemistry of early changes in young plants. Protoplasma, 191: 96-104.

Hayashi, T.; Yoshida, K. and Ohsumi, C. (1990), Regeneration of colchicine-induced single carrot cells. Agricultural and Biological Chemistry, 54, 1567-1568.

Joseleau, J.P.; Chambat, G.; Cortelazzo, A.L.; Faik, A. and Ruel, K. (1994), Putative biological action of oligosaccharides on enzymes involved in cell-wall development. Biochemical Society Transactions, 22, 404-409.

Joseleau, J.P.; Cortelazzo, A.L.; Chambat, G. and Ruel, K. (1996), Activation of peroxidases from plant cell suspensions by xyloglucan oligosaccharide elicitors. Plant Peroxidase Newsletter, 8, 8-13.

Khan, W.; Prithiviraj, B.; Smith, D.L. Chitosan and chitin oligomers increase phenylalanine ammonialyase and tyrosine ammonia-lyase activities in soybean leaves. Journal of Plant Physiology, 160, 859-863.

Levine, A.; Tenhaken, R.; Dixon, R.; Lambr, C. (1994) $\mathrm{H} 2 \mathrm{O} 2$ from the oxidative burst orchestrates the plant hypersensitive disease resistance response. Cell. 79, 705-714.

Lewis, N.G. and Yamamoto, E. (1990), Lignin: occurence, biogenesis and biodegradation. Annual Review Plant Physiology and Plant Molecular Biology, 41, 445-76.

McCready, R.M.; Guggolz, J.; Silveira, V. and Owens, H.S. (1950), Determination of starch and amylose in vegetables. Analytical Chemistry, 22, 1156-1158.

McDougall, G.J. and Fry, S.C. (1991), Xyloglucan nonasaccharide, a naturally occuring oligosaccharin, arises in vitro by polysaccharide breakdown. Journal of Plant Physiology, 137, 332-336. 
McDougall, G.J. and Fry, S.C. (1990), Xyloglucan oligosaccharides promote growth and activate cellulase: evidence for a role of cellulase in cell expansion. Plant Physiology, 93, 1042-1048.

McGhie, T.K.; Masel, N.P.; Maclean, D.; Croft, B.J. and Smith, G.R. (1997), Biochemical responses of suspension-cultured sugarcane cells to an elicitor derived from the root pathogen Pachymetra chaunorhiza. Australian Journal of Plant. Physiology, 24, 143-149.

Mello, M.L.S. and Vidal, B.C. (1978), A reação de Feulgen. Ciência e Cultura, 30, 665-676.

Melo, N.S.; Cabral J.M.S. and Fevereiro, M.P. (1995), Extracellular peroxidases from cell suspension cultures of Vaccinium myrtillus. Purification and characterization of two cationic enzymes. Plant Science, 106, 177-184.

Messner, B. and Boll, M. (1994), Cell suspension cultures of spruce (Picea abies): inactivation of extracellular enzymes by fungal elicitor-induced transient release of hydrogen peroxide (oxidative burst). Plant Cell Tissue and Organ Culture, 39, 6978.

Murashige, T. and Skoog, F. (1962), A revised medium for rapid growth and bioassays with tobacco tissue cultures. Physiologia Plantarum, 15, 473-497.

Peltonen, S.; Mannonen, L. and Karjalainen, R. (1997), Elicitor-induced changes of phenylalanine ammonialyase activity in barley cell suspension cultures. Plant Cell Tissue and Organ Culture, 50, 185-193.

Ramonell, K.M.; Zhang, B.; Ewing, R.M.; Chen, Y.; $\mathrm{Xu}$, D.; Stacey, G. and Somerville, S. (2002), Microarray analysis of chitin elicitation in Arabidopsis thaliana. Molecular Plant Pathology, 3(5), 301-311.

Ride, J.P. (1992), Recognition signals and initiation of host responses controlling basic incompatibility fungi and plants. Society for Experimental Biology and Seed Science, 48, 213-237.

Rohde, A.; Morreel, K.; Ralph, J.; Goeminne, G.; Hostyn, V.; Rycke, R.D; Kushnir, S.; Van Doorsselaere, J.; Joseleau, J.P.; Vuylsteke, M.; Van Driessche, G.; Beeumen, J.; Messens, E.; Boerjan, W. (2004), Molecular phenotyping of the pall and pal2 mutants of Arabidopsis thaliana reveals far-reaching consequences on phenylpropanoid, amino acid, and carbohydrate metabolism. The Plant Cell, 16, 27492771.

Ruel, K.; Cortelazzo, A,L,; Chambat, G.; Faïk, A.; Marais, M.F. and Joseleau, J.P. (1995), Rapid wall surface rearrangements induced by oligosaccharides in suspension-cultured cells. Current Issues in Plant Molecular and Cell Biology, 445-455.

Sancho, M.A.; Forchetti, S.M.; Pliego, F.; Valpuesta, V. and Quesada, M.A. (1996), Peroxidase activity and isoenzymes in the culture medium of $\mathrm{NaCl}$ adapted tomato suspension cells. Plant Cell Tissue and Organ Culture, 44, 161-167.
Sarosh, B.R.; Sivaramakrishnan, S.; Shetty, H.S. (2005), Elicitation of defense related enzymes and resistance by L-methionine in pearl millet against downy mildew disease caused by Sclerospora graminicola. Plant Physiology and Biochesmitry, 43, 808-815.

Schlob, P.; Walter, C. and Mäder, M. (1987), Basic peroxidases in isolated vacuoles of Nicotiana tabacum L. Planta, 170, 225-229.

Shibuya N, Minami E (2001) Oligosaccharide signalling for defense resposnses in plants. Physiology Molecular Plant Pathol. 59:223-233.

Silva, T.R.G.; Cortelazzo, A.L. and Dietrich, S.M.C. (1997) Cytological aspects of storage mobilization in seeds of Dalbergia miscolobium during germination and plantlet growth. Ciência e Cultura, 49, 219-222.

Spurr, A.R. (1969), A low viscosity epoxy resin embedding medium for electron microscopy. Journal Ultrastructure Reserch, 26, 31-43.

Stacey G, Shibuya N (1997) Chitin recognition in rice and legumes. Plant Soil. 194:161-169.

Sterjiades, R.; Dean, J.F.D.; Gamble, G.; Hemmelsbach, D.S. and Eriksson, K.E.L. (1993), Extracellular laccases and peroxidases from sycamore maple (Acer pseudoplatanus) cell-suspension cultures. Planta, 190, 75-87.

Usha, R.; Kiranmayee, P.; Madhavi, P, and Swamy, P.M. (2007) Phenyl alanine ammonia lyase activity and linalool contents of Artemisia pallens wall during callus growth. National Academy Science Letters, 30, 355-358.

Vallet, C.; Chabbert, B.; Czaninski, Y. and Monties, B. (1996), Histochemistry of lignin deposition during sclerenchyma differentiation in alfalfa stems. Annals of Botany, 78, 625-632.

Vander, P.; Varum, K.M; Domard, A.; Gueddari, N.E.E. and Moersschbacher, B.M. (1998), Comparasion of the ability of patially $\mathrm{N}$-acetylated chitosans and chitooligosacchacarides to elicit resistance reactions in wheat leaves. Plant Physiology, 118, 1353-1359.

Verpoorte, R.; Contin, A. and Memelink, J. (2002) Biotechnology for the production of plant secondary metabolites. Phytochemistry Review, 1, 13-25.

Vidal, B.C. (1977), Acid glycosaminoglycans and endochondral ossification: microspectophotometric evaluation and macromolecular orientation. Cell Molecular and Biology, 22, 45-64.

Villegas, M. and Brodelius, P.E. (1990), Elicitorinduced hydroxycinnamoyl-CoA: tyramine hydroxycinnamoyltransferase in plant cell suspension cultures. Physiology Plantarum, 78, 414-420.

Villiers, T.A. (1983), Ultrastructural changes in seed dormancy and senescence. In CRC Series in Aging: Senescence in plants (Thimann, K.V. ed), CRC Press, Boca Raton. p. 38-66.

Received: March 23, 2007 ; Revised: August 13, 2007; Accepted: June 01, 2009. 